\title{
OPINION ARTICLE \\ How Can We Achieve the UN Sustainable Development Goals?
}

\author{
Marc A. Rosen, Founding Editor-in-Chief ${ }^{1 *}$ \\ ${ }^{1}$ Faculty of Engineering and Applied Science, University of Ontario Institute of Technology, 2000 Simcoe Street North, \\ Oshawa, Ontario, L1H 7K4, Canada
}

*Corresponding Author: marc.rosen@uoit.ca

Citation: Rosen, M.A. (2017). How Can We Achieve the UN Sustainable Development Goals? European Journal of Sustainable Development Research, 1(2), 06.

doi: 10.20897/ejosdr.201706

Published: June 15, 2017

\begin{abstract}
With the approval of the UN Sustainable Development Goals comes several questions. How can we implement the UN Sustainable Development Goals at the national level? Must every country adopt and expend effort at achieving all of the goals? Or is it more suitable for countries to tailor the UN Sustainable Development Goals to the situations and priorities in their countries? The spirit of the agreement is reflected in the latter approach which, I feel, is the only practical way forward, if meaningful progress is to be made. To demonstrate this, an illustrative example is presented, describing the federal approach taken to achieving a sustainable future in one country, Canada.
\end{abstract}

Keywords: sustainable development, UN sustainable development goals, sustainable development strategy, Canada, sustainability

Progress is being made on the many efforts being expended on sustainable development, at the technical, social, environmental and political levels. This includes a fascinating array of research and development on many sustainable development-oriented innovations. These efforts often take a multidisciplinary approach that reflects the environmental, economic and societal pillars of sustainable development.

Of critical importance is the need to ensure sustainable development is incorporated broadly and pervasively into industry, government policy and actions, societal planning and development and people's lives. This includes efforts to develop coordinated strategies and policies that are sound, meaningful realistic and achievable.

Efforts at the political level are often highly visible and recently have been at the forefront. In particular, the UN Sustainable Development Goals were adopted by world leaders at the 70th Session of the UN General Assembly in 2015, as part of the 2030 Agenda for Sustainable Development (UN, 2015). The goals are wide ranging, seeking such laudable outcomes as ending poverty, eliminating inequality and injustice, and addressing climate change.

As the UN Sustainable Development Goals were prepared at a high level, with an aim to be suitable and acceptable to all countries, a key question arises: how can we implement the UN Sustainable Development Goals at the national level? And this question begets to several related questions. Must every country adopt and expend effort at achieving all of the goals? Or is it more suitable for countries to tailor the UN Sustainable Development Goals to the situations and priorities in their countries? The spirit of the agreement is reflected in the latter approach, given the detailed material on the goals. Furthermore, I feel that the latter approach is the only practical way forward, if meaningful progress is to be made.

The UN Sustainable Development Goals encompass 17 specific goals, which are outlined in Table 1. 
Table 1. UN Sustainable Development Goals.

\begin{tabular}{|c|c|}
\hline Goal number & Description \\
\hline 1 & End poverty in all its forms everywhere \\
\hline 2 & $\begin{array}{l}\text { End hunger, achieve food security and improved nutrition and promote sustainable } \\
\text { agriculture }\end{array}$ \\
\hline 3 & Ensure healthy lives and promote well-being for all at all ages \\
\hline 4 & $\begin{array}{l}\text { Ensure inclusive and equitable quality education and promote lifelong learning } \\
\text { opportunities for all }\end{array}$ \\
\hline 5 & Achieve gender equality and empower all women and girls \\
\hline 6 & Ensure availability and sustainable management of water and sanitation for all \\
\hline 7 & Ensure access to affordable, reliable, sustainable and modern energy for all \\
\hline 8 & $\begin{array}{l}\text { Promote sustained, inclusive and sustainable economic growth, full and productive } \\
\text { employment and decent work for all }\end{array}$ \\
\hline 9 & $\begin{array}{l}\text { Build resilient infrastructure, promote inclusive and sustainable industrialization and } \\
\text { foster innovation }\end{array}$ \\
\hline 10 & Reduce inequality within and among countries \\
\hline 11 & Make cities and human settlements inclusive, safe, resilient and sustainable \\
\hline 12 & Ensure sustainable consumption and production patterns \\
\hline 13 & Take urgent action to combat climate change and its impacts \\
\hline 14 & $\begin{array}{l}\text { Conserve and sustainably use the oceans, seas and marine resources for sustainable } \\
\text { development }\end{array}$ \\
\hline 15 & $\begin{array}{l}\text { Protect, restore and promote sustainable use of terrestrial ecosystems, sustainably } \\
\text { manage forests, combat desertification, and halt and reverse land degradation and } \\
\text { halt biodiversity loss }\end{array}$ \\
\hline 16 & $\begin{array}{l}\text { Promote peaceful and inclusive societies for sustainable development, provide } \\
\text { access to justice for all and build effective, accountable and inclusive institutions at } \\
\text { all levels }\end{array}$ \\
\hline 17 & $\begin{array}{l}\text { Strengthen the means of implementation and revitalize the global partnership for } \\
\text { sustainable development }\end{array}$ \\
\hline
\end{tabular}

Adapted from UN (2015).

Note that the UN Sustainable Development Goals did not come out of the blue as a new initiative or idea. They were a follow up to the UN Millennium Development Goals adopted by the international community in 2000 for a 15-year period. The UN Millennium Development Goals encompassed many sustainable development concepts, and led to numerous benefits. Examples in many countries include reduced levels of severe poverty, extreme hunger, and infant, child and maternal mortality. Additional achievements include improved access to safe drinking water, sanitation, and primary schooling for girls, and reductions in the spread of tuberculosis and HIV/AIDS. But much was left to be achieved. This UN Sustainable Development Goals extend the UN Millennium Development Goals notably. For instance, the formulation and focus is more encompassing, shifting the overall focus to improving the sustainability of global economic and social development and requiring participation from both wealthy and poor nations.

Despite the differences between the UN Sustainable Development Goals and the UN Millennium Development Goals, the important issue now is how to implement meaningfully and productively the UN Sustainable Development Goals to which so many countries have committed.

Taking a national approach to tailoring the objectives to a countries circumstances and priorities is beneficial and makes what appears to be an overwhelming challenge addressable and feasible. As an example, I describe here the federal approach taken in Canada. The federal government recently released its strategy, entitled "Achieving a Sustainable Future: A Federal Sustainable Development Strategy for Canada - 2016-2019” (Canada, 2016). It sets out the country's sustainable development priorities, establishes goals and targets, and identifies actions to achieve them. Under a federal act that provides the legal framework for developing and implementing a government strategy every three years, the most recent strategy was released in 2016 outlining what Canada will do to promote clean growth, ensure healthy ecosystems and build safe, secure and sustainable communities. The development process incorporates public input and has 13 aspirational goals (see Table 2). These in essence are a Canadian reflection of the environmentally-related sustainable development goals of the 2030 Agenda for Sustainable 
Development, reflecting a national approach to the international agreement and reflecting the circumstances and priorities in the country.

Table 2. Federal Sustainable Development Strategy for Canada.

\begin{tabular}{|c|c|c|}
\hline Goal & Goal description & Target \\
\hline $\begin{array}{l}\text { Effective } \\
\text { action on } \\
\text { climate change }\end{array}$ & $\begin{array}{l}\text { A low-carbon economy } \\
\text { contributes to limiting global } \\
\text { average temperature rise to well } \\
\text { below two degrees Celsius and } \\
\text { supports efforts to limit the } \\
\text { increase to } 1.5^{\circ} \mathrm{C}\end{array}$ & $\begin{array}{l}\text { By } 2030 \text {, reduce Canada's total GHG emissions by } 30 \% \text {, } \\
\text { relative to } 2005 \text { emission levels }\end{array}$ \\
\hline $\begin{array}{l}\text { Low-carbon } \\
\text { government }\end{array}$ & $\begin{array}{l}\text { The Government of Canada } \\
\text { leads by example by making its } \\
\text { operations low-carbon }\end{array}$ & $\begin{array}{l}\text { Reduce GHG emissions from federal government buildings } \\
\text { and fleets by } 40 \% \text { below } 2005 \text { levels by } 2030 \text {, with an } \\
\text { aspiration to achieve it by } 2025\end{array}$ \\
\hline Clean growth & $\begin{array}{l}\text { A growing clean technology } \\
\text { industry in Canada contributes } \\
\text { to clean growth and the } \\
\text { transition to a low-carbon } \\
\text { economy }\end{array}$ & $\begin{array}{l}\text { Implement our Mission Innovation commitment to double } \\
\text { federal government investments in clean energy research, } \\
\text { development and demonstration, by } 2020 \text {, from } 2015 \text { levels }\end{array}$ \\
\hline $\begin{array}{l}\text { Modern and } \\
\text { resilient } \\
\text { infrastructure }\end{array}$ & $\begin{array}{l}\text { Modern, sustainable, and } \\
\text { resilient infrastructure supports } \\
\text { clean economic growth and } \\
\text { social inclusion }\end{array}$ & $\begin{array}{l}\text { By the end of } 2025-2026 \text {, invest } \$ 20 \text { billion in funding for } \\
\text { green infrastructure initiatives that reduce GHG emissions and } \\
\text { improve climate resilience and environmental quality }\end{array}$ \\
\hline Clean energy & $\begin{array}{|ll|}\text { All Canadians } & \text { have access to } \\
\text { affordable, reliable and } \\
\text { sustainable energy }\end{array}$ & $\begin{array}{l}\text { By 2030, } 90 \% \text { and in the long term, } 100 \% \text { of Canada's } \\
\text { electricity is generated from renewable and non-emitting } \\
\text { sources; by } 2025 \text {, contribute to the North American goal of } \\
50 \% \text { clean power generation; by } 2019 \text {, there is a favourable } \\
\text { five-year trend in renewable electricity capacity compared to } \\
\text { overall electricity sources, from a } 2014 \text { level of } 64.4 \%\end{array}$ \\
\hline $\begin{array}{l}\text { y coasts } \\
\text { eans }\end{array}$ & $\begin{array}{l}\text { Coasts and oceans support } \\
\text { healthy, resilient and productive } \\
\text { ecosystems }\end{array}$ & $\begin{array}{l}\text { By } 2020,10 \% \text { of coastal and marine areas are conserved } \\
\text { through networks of protected areas and other effective area- } \\
\text { based conservation measures; by } 2020 \text {, all fish and invertebrate } \\
\text { stocks and aquatic plants are managed and harvested } \\
\text { sustainably, legally and applying ecosystem-based approaches } \\
\text { starting at } 96 \% \text { in } 2015\end{array}$ \\
\hline $\begin{array}{l}\text { Pristine lakes } \\
\text { and rivers }\end{array}$ & $\begin{array}{l}\text { Clean and healthy lakes and } \\
\text { rivers support economic } \\
\text { prosperity and the well-being of } \\
\text { Canadians }\end{array}$ & $\begin{array}{l}\text { Reduce nutrient pollution to lakes and rivers; restore lake and } \\
\text { river ecosystems }\end{array}$ \\
\hline $\begin{array}{l}\text { Sustainably } \\
\text { managed lands } \\
\text { and forests }\end{array}$ & $\begin{array}{l}\text { Lands and forests support } \\
\text { biodiversity and provide a } \\
\text { variety of ecosystem services for } \\
\text { generations to come }\end{array}$ & $\begin{array}{l}\text { By } 2020 \text {, at least } 17 \% \text { of terrestrial areas and inland water are } \\
\text { conserved through networks of protected areas and other } \\
\text { effective area-based conservation measures; by 2019, the } \\
\text { condition of } 90 \% \text { of ecological integrity indicators in national } \\
\text { parks is maintained or improved; between now and } 2020 \text {, } \\
\text { maintain Canada's annual timber harvest at or below } \\
\text { sustainable wood supply levels }\end{array}$ \\
\hline $\begin{array}{l}\text { Healthy } \\
\text { wildlife } \\
\text { populations }\end{array}$ & $\begin{array}{l}\text { All species have healthy and } \\
\text { viable populations }\end{array}$ & $\begin{array}{l}\text { By } 2020 \text {, species that are secure remain secure, and populations } \\
\text { of species at risk listed under federal law exhibit trends that are } \\
\text { consistent with recovery strategies and management plans; by } \\
2025,59 \% \text { of managed migratory bird species have population } \\
\text { sizes within an acceptable range }\end{array}$ \\
\hline $\begin{array}{l}\text { Clean drinking } \\
\text { water }\end{array}$ & $\begin{array}{l}\text { All Canadians have access to } \\
\text { safe drinking water and, in } \\
\text { particular, the significant } \\
\text { challenges } \\
\text { communities face are addressed }\end{array}$ & $\begin{array}{l}\text { By March 31, 2019, 60\% and by March 31, } 2021100 \% \text { of the } \\
\text { long-term drinking water advisories affecting First Nation } \\
\text { drinking water systems financially supported by Indigenous } \\
\text { and Northern Affairs Canada are to be resolved }\end{array}$ \\
\hline
\end{tabular}


Table 2 (continued). Federal Sustainable Development Strategy for Canada.

\begin{tabular}{|c|c|c|}
\hline $\begin{array}{l}\text { Sustainable } \\
\text { food }\end{array}$ & $\begin{array}{l}\text { Innovation and ingenuity } \\
\text { contribute to a world-leading } \\
\text { agricultural sector and food } \\
\text { economy for the benefit of all } \\
\text { Canadians }\end{array}$ & $\begin{array}{l}\text { Ensure safe and accessible food supply by mitigating risks to } \\
\text { animal and plant resources from pests, diseases and other } \\
\text { health hazards and prevent risks to health of Canadians; by } \\
2030 \text {, agricultural working landscapes provide a stable or } \\
\text { improved level of biodiversity and efficient management } \\
\text { towards water and soil quality for food production; by } 2020 \text {, } \\
\text { all aquaculture in Canada is managed under a science-based } \\
\text { regime that promotes the sustainable use of aquatic resources } \\
\text { (marine and freshwater) in ways that conserve biodiversity }\end{array}$ \\
\hline $\begin{array}{l}\text { Connecting } \\
\text { Canadians } \\
\text { with nature }\end{array}$ & $\begin{array}{l}\text { Canadians are informed about } \\
\text { the value of nature, } \\
\text { experiencing nature first hand, } \\
\text { and actively engaged in its } \\
\text { stewardship }\end{array}$ & $\begin{array}{l}\text { By } 2020 \text {, maintain or increase the number of Canadians that } \\
\text { get out into nature-for example, by visiting parks and green } \\
\text { spaces-and increase participation in biodiversity } \\
\text { conservation activities relative to a } 2010 \text { baseline }\end{array}$ \\
\hline $\begin{array}{l}\text { Safe and } \\
\text { healthy } \\
\text { communities }\end{array}$ & $\begin{array}{l}\text { All Canadians live in clean, } \\
\text { sustainable communities that } \\
\text { contribute to their health and } \\
\text { well-being }\end{array}$ & $\begin{array}{l}\text { Implement the Air Quality Management System to: decrease } \\
\text { the three-year average of particulate matter, nitrogen oxide and } \\
\text { volatile organic compound emissions from regulated and/or } \\
\text { targeted sources to below the previous three-year average, and } \\
\text { increase the percentage of the Canadian population living in } \\
\text { areas where measured outdoor concentrations are below the } \\
\text { Canadian Ambient Air Quality Standards (CAAQS) for fine } \\
\text { particulate matter and ozone compared to the year 2000; by } \\
\text { 2020, address the 4,300 substances identified as priorities for } \\
\text { action under the Chemicals Management Plan }\end{array}$ \\
\hline
\end{tabular}

Adapted from Canada (2016).

The illustrative example presented for Canada shows how a country can tailor the UN Sustainable Development Goals to its situations and priorities, in order to move forward towards achieving a sustainable future. I feel it provides an interesting and positive example of how countries can implement the UN Sustainable Development Goals at the national level. This example is by no means presented as the correct or only example, but rather is provided simply as an illustration. In fact, other nations have also put forward their plans to address the UN Sustainable Development Goals to the in their countries.

I feel that national strategies and actions provide the best practical way forward, if meaningful progress is to be made on achieving the UN Sustainable Development Goals in particular and moving towards sustainable development globally in general.

\section{REFERENCES}

UN. 2015. Resolution adopted by the General Assembly on 25 September 2015. A/RES/70/1. Seventieth session. United Nations.

Canada. 2016. Achieving a Sustainable Future: A Federal Sustainable Development Strategy for Canada - 20162019, Government of Canada. 